\title{
Modern technologies for improving cleaning and disinfection of environmental surfaces in hospitals
}

John M. Boyce

\begin{abstract}
Experts agree that careful cleaning and disinfection of environmental surfaces are essential elements of effective infection prevention programs. However, traditional manual cleaning and disinfection practices in hospitals are often suboptimal. This is often due in part to a variety of personnel issues that many Environmental Services departments encounter. Failure to follow manufacturer's recommendations for disinfectant use and lack of antimicrobial activity of some disinfectants against healthcare-associated pathogens may also affect the efficacy of disinfection practices.

Improved hydrogen peroxide-based liquid surface disinfectants and a combination product containing peracetic acid and hydrogen peroxide are effective alternatives to disinfectants currently in widespread use, and electrolyzed water (hypochlorous acid) and cold atmospheric pressure plasma show potential for use in hospitals. Creating "self-disinfecting" surfaces by coating medical equipment with metals such as copper or silver, or applying liquid compounds that have persistent antimicrobial activity surfaces are additional strategies that require further investigation.

Newer "no-touch" (automated) decontamination technologies include aerosol and vaporized hydrogen peroxide, mobile devices that emit continuous ultraviolet (UV-C) light, a pulsed-xenon UV light system, and use of high-intensity narrow-spectrum (405 nm) light. These "no-touch" technologies have been shown to reduce bacterial contamination of surfaces. A micro-condensation hydrogen peroxide system has been associated in multiple studies with reductions in healthcare-associated colonization or infection, while there is more limited evidence of infection reduction by the pulsed-xenon system. A recently completed prospective, randomized controlled trial of continuous UV-C light should help determine the extent to which this technology can reduce healthcare-associated colonization and infections. In conclusion, continued efforts to improve traditional manual disinfection of surfaces are needed. In addition, Environmental Services departments should consider the use of newer disinfectants and no-touch decontamination technologies to improve disinfection of surfaces in healthcare.
\end{abstract}

Keywords: Disinfection, Disinfectants, Cleaning, Ultraviolet light, UV-C, Hydrogen peroxide vapor

\section{Background}

In recent years, there is an increasing consensus that improved cleaning and disinfection of environmental surfaces is needed in healthcare facilities [1-4]. Experts generally agree on a number of areas, including the fact that careful cleaning and/or disinfection of environmental surfaces, daily and at time of patient discharge, are essential elements of effective infection prevention programs. Moreover, when disinfectants are used, they must be used appropriately to achieve the desired effects. However, there are a number of areas of disagreement and controversy regarding best practices for cleaning and disinfection of environmental surfaces. Some experts favor physical removal of microorganisms using only a detergent solution [3]. Other individuals believe that manual disinfection of surfaces using currently available disinfectants is adequate, and that newer approaches to disinfection are not necessary.

The purpose of this article is to summarize the many factors that affect standard cleaning and disinfection practices and to discuss modern technologies that can supplement traditional cleaning and disinfection methods.

Correspondence: jmboyce69@gmail.com

J.M. Boyce Consulting, LLC, 62 Sonoma Lane, Middletown, CT 06457, USA 


\section{Personnel-related issues}

Multiple studies have shown that manual cleaning and disinfection of surfaces in hospitals is suboptimal. In many facilities, only 40 to $50 \%$ of surfaces that should be cleaned are wiped by housekeepers [5]. In addition, observational methods combined with use of adenosine triphosphate (ATP) bioluminescence have shown that individual housekeeper performance varies considerably [6]. One study found variations among housekeepers in the amount of time spent cleaning surfaces, the number of wipes used in each room, and the level of cleanliness achieved [6]. Specialized cleaning teams that included infection control personnel have been shown to reduce C. difficile surface contamination more effectively than routine housekeepers [7]. Personnel turnover among Environmental Services departments is a significant problem $[8,9]$, which may reach 30 to $50 \%$ in some facilities. As a result, shortages in Environmental Services personnel were reported by more than $50 \%$ of hospitals in a recent survey conducted in the United States [10]. Among housekeepers and nursing personnel, there is often confusion about who is responsible for cleaning various surfaces and equipment $[11,12]$.

\section{Issues related to disinfection protocols and practices}

In addition to the above personnel-related issues, there are many other factors that can potentially have adverse effects on the efficacy of traditional cleaning and disinfection practices. The type of surface being cleaned or disinfected can affect the completeness with which bacteria are removed. For example, Ali et al. found that the type of material from which bed rails were made affected how well they could be cleaned by microfiber cloths, and that bacteria were removed more effectively by antibacterial wipes than by microfiber [13]. Disinfectants may be applied using inadequate contact times. Failure of housekeepers to use an adequate number of wipes per room can result in poor cleaning of surfaces [6]. Use of wipes without sufficient antimicrobial activity against target pathogens can result in poor disinfection of surfaces and can lead to spread of pathogens from one surface to another $[14,15]$. Binding of quaternary ammonium disinfectants to cloths made of cotton or wipes containing substantial amounts of cellulose may reduce the antimicrobial efficacy of the disinfectant $[16,17]$. At least one laboratory-based study has shown that detergent wipes have variable ability to remove pathogens from surfaces, and may in fact transfer pathogens between surfaces [18].

Inappropriate over-dilution of disinfectant solutions by housekeepers or by malfunctioning automated dilution systems may result in applying disinfectants using inappropriately low concentrations [9, 17]. For example, an investigation of housekeeping practices at a large teaching hospital included an audit of 33 automated disinfectant dispensing stations that mix concentrated disinfectant with water to yield a desired in-use quaternary ammonium concentration of 800 ppm [17]. Quaternary ammonium concentrations of solutions dispensed were tested using commercially-available test strips. The audit revealed that several dispensing stations yielded solutions with less than $200 \mathrm{ppm}$, approximately $50 \%$ of stations delivered solutions with 200 to 400 ppm. An investigation revealed several flaws in the dispensing system. Inexpensive test strips and more complicated titration kits are available to monitor quaternary ammonium concentrations of disinfectants.

Contamination of disinfectant solutions can occur, particularly if recommendations for their use are not followed [19-21]. For example, Kampf et al. recently reported that 28 buckets from 9 hospitals contained surface-active disinfectants (e.g., quarternary ammomium solutions) that were contaminated with Achromobacter or Serratia strains [21]. Buckets and roles of wipes had not been handled according to manufacturer recommendations. In studies that involved culturing high-touch surfaces in patient rooms before and shortly after housekeepers had performed routine cleaning, we found that cultures obtained from several surfaces in one room after cleaning yielded large numbers of Serratia and smaller numbers of Achromobacter which were not present before cleaning [Fig. 1] [20]. The housekeeper's bucket of quaternary ammoniumbased disinfectant contained $9.3 \times 10^{4} \mathrm{CFUs} / \mathrm{ml}$ of gramnegative bacilli (mostly Serratia marcescens and fewer numbers of Achromobacter xylosoxidans). Pulsed-field gel electrophoresis demonstrated that Serratia isolates recovered from the disinfectant were the same strains as those recovered from surfaces in the patient room. Genome sequencing of one of the Serratia strains by collaborating investigators revealed that it contained four different qac resistance genes that permitted the organism to grow and survive in the disinfectant (unpublished data). If

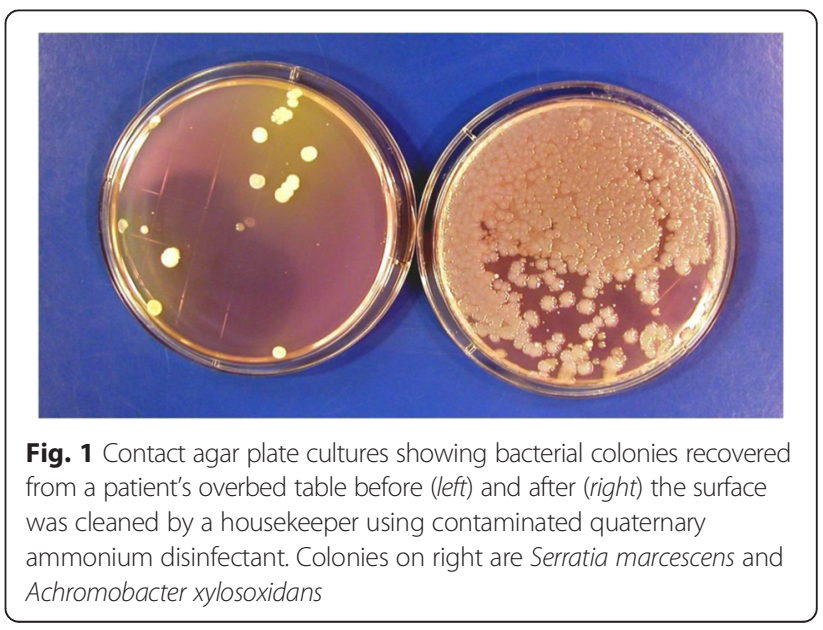


disinfectant contamination is suspected, a sample of the product can be used to inoculate a broth medium or solid agar containing neutralizers effective against the active agent(s) in the disinfectant solution.

Numerous studies have found that standard manual cleaning or disinfection of surfaces can reduce, but often does not eliminate, important pathogens such as C. difficile, staphylococci including methicillin-resistant Staphylococcus aureus (MRSA), vancomycin-resistant enterococci (VRE), and multi-drug-resistant Acinetobacter [7, 22-28]. Failure to adequately disinfect patient rooms at the time of hospital discharge contributes to the increased risk of acquisition of resistant pathogens among patients admitted to a room where the prior room occupant was colonized or infected with a multidrug-resistant pathogen [29-31].

\section{Monitoring housekeeping practices}

In order to improve standard cleaning and disinfection practices, it is recommended that the practices of housekeepers be monitored and that they receive feedback regarding their performance. However, monitoring of housekeeper performance is often not performed as frequently as needed, if at all [10]. Recently, fluorescent marking systems (Fig. 2) and ATP bioluminescence assays (Fig. 3) have proven useful for evaluating cleaning practices and providing housekeepers with feedback [32, 33]. Unfortunately, such objective means of monitoring the adequacy of cleaning/disinfection practices are not routinely used in many facilities [10]. Perhaps the lack of monitoring of housekeepers is due in part to the fact that monitoring activities can be time-consuming and must be conducted on an ongoing basis in order to be effective [34].

Given the multitude of challenges to achieving and maintaining adequate cleaning and disinfection in healthcare facilities, there is a need to consider the use of modern technologies designed to improve disinfection of surfaces in hospitals. New technologies fall into several categories, including: (A) new liquid surface disinfectants, (B) improved methods for applying disinfectants, (C) selfdisinfecting surfaces, (D) light-activated photosensitizers, and (E) no-touch (automated) technologies.

\section{New liquid disinfectants}

New disinfectants that are currently available or under development include improved hydrogen peroxide liquid disinfectants, peracetic acid-hydrogen peroxide combination, electrolyzed water, cold atmospheric pressure plasma, and polymeric guanidine. Several improved hydrogen peroxide disinfectants have been shown to be effective one-step cleaner/disinfectant agents that significantly reduce bacterial levels on surfaces [35-38]. In one study, use of a product containing $0.5 \%$ (weight/volume) improved hydrogen peroxide was associated with fewer healthcare-associated infections when compared to an existing cleaning product, although all potential confounding variables were not analyzed [38]. Improved hydrogen peroxide liquid disinfectants can also be used to reduce contamination by multidrug-resistant pathogens on soft surfaces such as bedside curtains [14, 39]. Several of the improved hydrogen peroxide disinfectants also have activity against norovirus surrogate viruses, although they are not as potent as sodium hypochlorite (bleach) solutions [40]. These newer disinfectants have Environmental Protection Agency (EPA) safety rating of category IV (housekeepers do not need to wear any personal protective equipment while using these products).

A new sporicidal disinfectant that contains both peracetic acid and hydrogen peroxide has been shown to reduce bacterial levels on surfaces to a greater degree than a quaternary ammonium disinfectant in one study, and reduced contamination by C.difficile, MRSA, and VRE as effectively as sodium hypochlorite in another study [41, 42]. The product has a smell similar to vinegar that may be of concern when it is initially

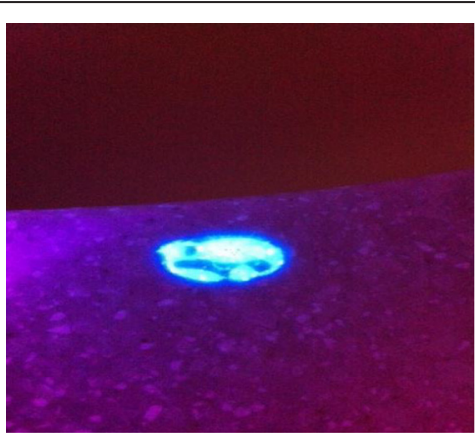

Before marked surface was wiped

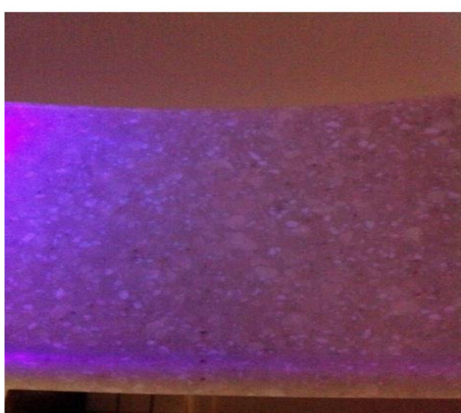

After marked surface was wiped

Fig. 2 Photographs of a fluorescent marker visible with a "black light" on a high touch surface before cleaning (left), and absence of the fluorescent marker after cleaning was performed (right) 

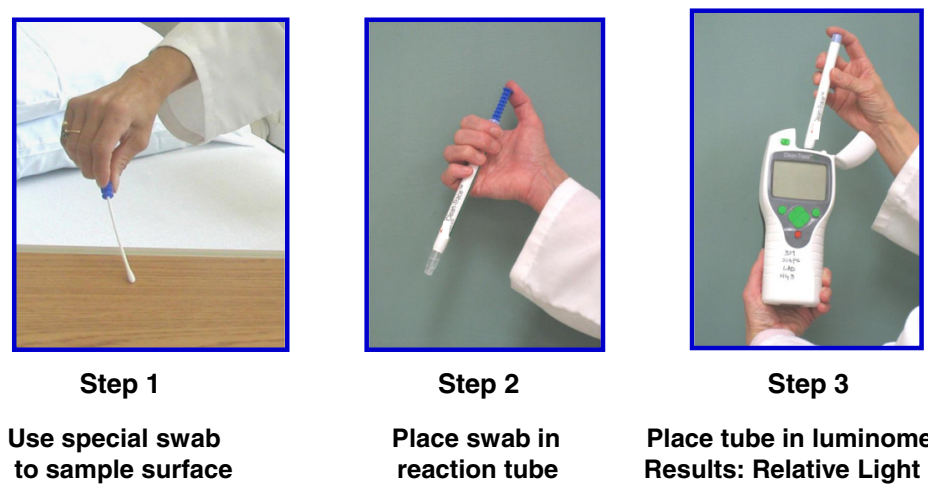

Place tube in luminometer Results: Relative Light Units

Fig. 3 Three steps of an ATP bioluminescence assay for monitoring cleanliness of surfaces. Step 1: a special swab is used to sample the surface. Step 2: the swab is placed in a reaction tube and shaken for 10-15 s. Step 3: the reaction tube is placed in a luminometer and a result is reported as relative light units (RLUs). The higher the RLU value, the greater the amount of ATP detected on the surface

introduced. The combination product gives hospitals a potential alternative to sodium hypochlorite when a sporicidal disinfectant is needed.

Electrolyzed water (hypochlorous acid) disinfectant is produced by passing current through a solution of water and salt [43-45]. This promising disinfectant was shown to reduce bacterial levels on surfaces near patients to greater degree than a quaternary ammonium disinfectant in one study [43]. In another study, an electrolyzed water disinfectant significantly reduced MRSA, VRE and C. difficile spores in in-vitro experiments, and significantly reduced aerobic bacteria and $C$. difficile spores when sprayed onto medical equipment [44]. Spraying equipment was simple, required only approximately $15 \mathrm{~s}$ per application, and could be left to dry without wiping. One group of investigators found that electrolyzed water effectively reduced the number of aerobic bacteria (including staphylococci) on near-patient surfaces, but for reasons not well understood, appeared to allow regrowth of staphylococci within $24 \mathrm{~h}$ of application [45]. Further studies of this phenomenon are warranted. Electrolyzed water has the advantage of not leaving any toxic residues on surfaces. Issues related to stability of such products and logistic issues related to its use require additional study.

Cold-air atmospheric pressure plasma systems are being investigated for possible use as surface disinfectants in healthcare facilities [46-48]. In laboratory studies, the reactive oxygen species generated by these systems have bactericidal activity against a variety of pathogens, with variable activity against $C$. difficile spores [48]. Much more experience with cold-air atmospheric pressure plasma systems is needed to determine the practicality, efficacy and safety of using such systems in hospital settings. A novel nebulized solution of polymeric guanidine has been shown in one study to have antimicrobial activity against several healthcare-associated pathogens, and may warrant further investigation [49].

\section{New methods for applying disinfectants}

Microfiber cloths or mops and ultramicrofiber cloths are among the relatively newer methods for applying liquid disinfectants to surfaces [50-54]. Some studies have shown increased cleaning efficacy of microfiber or ultramicrofiber cloths compared to standard cotton cloth or mops [51, 55]. However, it appears that all microfiber wipes are not equally effective [50]. Furthermore, if not used properly, there is some evidence that they may actually spread bacteria to other surfaces $[53,54]$. When using microfiber cloths or mops, is important to know that the durability of these products is adversely affected by hypochlorite and high temperatures used during laundering and drying, and that their performance may decrease after multiple washings. One of the advantages of microfiber over cotton cloths is that microfiber is less likely than cotton cloths to bind quaternary ammonium disinfectants [16, 17]. However, presently, it is not clear how much the lower binding of microfiber cloths to quaternary ammonium disinfectants effects eradication of bacteria from contaminated surfaces. Additional studies are needed to better define the relative advantages and disadvantages of applying surface disinfectants with microfiber, cotton cloths and spunlace non-woven disposable wipes.

\section{Self-disinfecting surfaces}

Creating "self-disinfecting surfaces" by coating surfaces with heavy metals such as copper or silver that have innate antimicrobial properties or applying to surfaces compounds that retain their antimicrobial activity for weeks or months has received some attention as a new strategy for disinfecting or preventing the growth of 
bacteria on surfaces in hospitals [56, 57]. Silver binds strongly with disulfide and sulfhydryl groups present in proteins of microbial cell walls, leading to cell death [56]. The antimicrobial activity of copper may be due primarily to its ability to form reactive oxygen radicals that damage nucleic acid and proteins [56]. Impregnating equipment surfaces with copper alloys has been shown to reduce bacterial contamination of surfaces [58-60], and in one study, coating several surfaces in hospital rooms with copper alloy was associated with reduction in incidence of HAIs [60]. Further studies of the long-term antimicrobial potency, practicality and costeffectiveness of copper-coated surfaces are needed. Privacy curtains impregnated with silver have been shown to reduce or delay contamination of curtains with potential pathogens $[61,62]$.

Organosilane compounds are comprised of a surfactant plus an antimicrobial substance such as a quaternary ammonium moiety. These compounds are designed to minimize bacterial contamination of surfaces by maintaining their antimicrobial activity on surfaces for weeks or months. To date, the ability of these compounds to prevent contamination of surfaces for prolonged time periods is unclear. One study that applied compounds to surfaces using microfiber cloths failed to demonstrate continuing antimicrobial activity, where as two other studies using different application methods reported persistent antimicrobial activity of varying levels for differing time periods [63-65]. Further evaluation of organosilane-type compounds using a variety of application methods appears warranted. Polyhexamethylene biguanide disinfectant was found to reduce bacterial levels on surfaces for at least $24 \mathrm{~h}$ after application in one study [66].

\section{Light-activated photosensitizers}

A few studies have explored the potential of applying of light-activated photosensitizers such as nanosized titanium dioxide to surfaces and using UV light to generate reactive oxygen species that can disinfect surfaces [67-70]. Activated titanium dioxide has been shown to have varying antimicrobial activity, with the relative susceptibility of agents against pathogens. Research on the use of lightactivated photosensitizers is in early stages, and much more information about the feasibility and safety of using this strategy is needed.

\section{No-touch room decontamination methods}

Examples of no-touch room decontamination technologies include: aerosolized hydrogen peroxide, hydrogen peroxide vapor systems, gaseous ozone, chlorine dioxide, saturated steam systems, peracetic acid/hydrogen peroxide fogging, mobile continuous ultraviolet devices, pulsed- xenon light devices, and high-intensity narrow-spectrum (405 nm) light [1, 3, 4, 71, 72].

\section{Aerosolized hydrogen peroxide}

Aerosolized hydrogen peroxide systems that utilize 3 to $7 \%$ hydrogen peroxide with or without the addition of silver ions have been evaluated by several investigators [25, 73-79]. Aerosols (which are not vapor) generally have particle sizes ranging from 2 to $12 \mu$, are injected into a room, followed by passive aeration. These systems have been shown to significantly reduce bacteria, generally a $4 \log _{10}$ reduction of spores, although in several studies spores were not completely eradicated. One system has a sporicidal claim from the EPA in the United States. In one study, use of the aerosolized hydrogen peroxide system was associated with a reduction in C. difficile infection, and possible reduction of MRSA acquisition in a second study [25]. Like many other strategies in infection control, there are currently no randomized controlled trials of the efficacy of these systems in preventing health-care-associated infections.

\section{Hydrogen peroxide vapor}

A "dry gas" vaporized hydrogen peroxide system that utilizes $30 \%$ hydrogen peroxide has been shown to be effective against a variety of pathogens, including Mycobacterium tuberculosis, Mycoplasma, Acinetobacter, C. difficile, Bacillus anthracis, viruses, and prions [80-83]. In before/after studies, dry gas vaporized hydrogen peroxide system, when combined with other infection control measures, appears to have contributed to control of outbreaks of Acinetobacter in a long-term care facility and in two intensive care units in a hospital [84-86]. However, long cycle times have made it difficult to implement this system in healthcare facilities.

A micro-condensation hydrogen peroxide vapor system, which utilizes $35 \%$ hydrogen peroxide, is effective in eradicating important pathogens including MRSA, VRE, $C$. difficile, Klebsiella, Acinetobacter, Serratia, Mycobacterium tuberculosis, fungi, and viruses. Laboratory-based and inhospital studies documented significant reductions (often $10^{6} \log _{10}$ ) of a number of these pathogens, with 92 to $100 \%$ reduction of pathogens on surfaces [23, 83, 87-93]. In before/after trials, when used in conjunction with other measures, the micro-condensation hydrogen peroxide vapor system appears to have contributed to control of outbreaks caused by MRSA, multi drug-resistant Gramnegative bacteria, and $C$. difficile [78, 87, 94-99]. A prospective, controlled trial performed by Passaretti et al. demonstrated significant reduction in the risk of acquiring multidrug-resistant organisms (MDROs), especially VRE [30]. It has also been used to decontaminate the packaging of unused medical supplies removed from isolation rooms, instead of discarding such items [100]. This system has 
also been used to decontaminate rooms previously occupied by patients with the Lassa fever and Ebola virus infection [101, 102]. Despite the demonstrated ability of this system to eradicate nosocomial pathogens from surfaces, concerns over its cost and room turn-around-times have hampered adoption of this technology in healthcare settings. At least one study found that the microcondensation hydrogen peroxide system can be implemented in hospitals when census levels are relatively high [103]. Recent improvements in the efficiency of the system permit more rapid turn-around-times than earlier equipment, which may lead to wider adoption. To date, there are no randomized, controlled trials establishing the impact of the micro-condensation hydrogen peroxide system on reduction of healthcare-associated infections. Other vapor- or aerosol-based no-touch disinfection technologies that have been described, but whose adoption appears to be limited include gaseous ozone, chlorine dioxide gas, and saturated steam systems [104-109].

\section{Ultraviolet light devices}

Automated mobile ultraviolet light devices that continuously emit UV-C in the range of $254 \mathrm{~nm}$ can be placed in patient rooms after patient discharge and terminal cleaning has been performed. A number of these devices can be set to kill vegetative bacteria or to kill spores. These systems often reduce the VRE and MRSA by four or more $\log _{10}$, and C. difficile by $1-3 \log _{10}$ [110-118]. In one comparative trial, a continuous UV-C light system resulted in lower log reductions than a microcondensation hydrogen peroxide vapor system [119]. Advantages of the mobile, continuous UV-C light devices include their ease of use, minimal need for special training of environmental services personnel, and unlike hydrogen peroxide vapor systems, the ability to utilize the devices without having to seal room vents or doors. Recently, a prospective, multicenter randomized controlled trial comparing a mobile continuous UV-C light system with standard and other enhanced surface disinfection methods has been completed [120]. Results of the trial should be published in the near future.

A pulsed-xenon device, which does not use mercury bulbs to produce UV light, emits light in the 200$320 \mathrm{~nm}$ range. It has been shown to significantly reduce pathogens in patient rooms [121-127]. The manufacturer recommends placing device in 3 locations in a room with 5-7 min cycles (shorter than with some continuous UV-C systems). While a few studies utilizing the device reported reductions in $C$. difficile infection [122, 127], a more recent 8-month study in a large institution found no significant reduction in $C$. difficile infection rates hospital-wide or on four units with high $C$. difficile infection rates [128]. One carefully-performed trial which compared the pulsed-xenon system with a continuous UV-C light device found that $\log _{10}$ reductions of pathogens achieved with the pulsed-xenon system were lower than with the continuous UV-C light device [129]. Additional evaluation of the pulsed-xenon UV system by independent investigators is needed.

\section{High-intensity narrow-spectrum light}

High-intensity narrow-spectrum (HINS) light, which is visible violet-blue light in the range of $405 \mathrm{~nm}$ has been tested as a means of disinfecting air and surfaces and hospital rooms. This technology targets intracellular porphyrins that absorb the light and produce reactive oxygen species [130-132]. Its antimicrobial efficacy is lower than UV-C light, but it can be used in areas occupied by patients. In one study, continuous HINS light showed a 27 to $75 \%$ reduction in surface contamination by staphylococci compared to control areas [131]. Further investigation of this technology, including its level of activity against $C$. difficile, appears warranted.

\section{Photocatalytic disinfection}

An enclosed air purifying system designed for use by NASA utilizes UV-activated titanium dioxide photocatalytic reactions to oxidize volatile organic compounds and airborne microorganisms. Since aerosolization of pathogens such as $S$. aureus and C. difficile during patient care activities is known to occur, there may be some interest in using such systems in patient rooms to reduce airborne bacteria may settle onto environmental surfaces [133].

Given the increasing interest in the above-mentioned new technologies for cleaning and disinfection of environmental surfaces, the Agency for Healthcare Research and Quality (AHRQ) recently commissioned an expert panel to review data regarding these modern technologies. The panel concluded that there is a relative lack of comparative studies addressing the relative effectiveness of various cleaning, disinfecting and monitoring strategies, and that future studies are needed that directly compare newer disinfecting and monitoring methods to one another and with traditional methods [4].

\section{Conclusions}

In conclusion, manual cleaning and disinfection of environmental surfaces in healthcare facilities (daily and at patient discharge) are essential elements of infection prevention programs. Because many factors make it difficult to achieve high rates of effective disinfection on a routine and sustained basis, continued efforts to improve the quality and consistency of traditional cleaning and disinfection practices are needed. Given the many challenges in achieving desired levels of surface disinfection, adoption of modern technologies is indicated to supplement traditional methods. Further research into the 
efficacy and cost-effectiveness of newer technologies, and when to best apply them, is needed. As additional data become available, it is likely that newer liquid disinfectants and some no-touch room decontamination systems will be more widely adopted to supplement traditional cleaning and disinfection practices.

\section{Competing interests}

J.M.B. is a consultant to 3 M Company, Bioquell, Clorox Company, and Diversey Care.

Received: 11 November 2015 Accepted: 23 March 2016

Published online: 11 April 2016

\section{References}

1. Rutala WA, Weber DJ. Disinfectants used for environmental disinfection and new room decontamination technology. Am J Infect Control. 2013;41:S36-41.

2. Donskey CJ. Does improving surface cleaning and disinfection reduce health care-associated infections? Am J Infect Control. 2013;41:S12-9.

3. Dancer SJ. Controlling hospital-acquired infection: focus on the role of the environment and new technologies for decontamination. Clin Microbiol Rev. 2014;27:665-90.

4. Han JH, Sullivan N, Leas BF, Pegues DA, Kaczmarek JL, Umscheid CA. Cleaning hospital room surfaces to prevent health care-associated infections. a technical brief. Ann Intern Med. 2015;163:598-607.

5. Carling PC, Bartley JM. Evaluating hygienic cleaning in health care settings: what you do not know can harm your patients. Am J Infect Control. 2010:38:541-50.

6. Boyce JM, Havill NL, Lipka A, Havill H, Rizvani R. Variations in hospital daily cleaning practices. Infect Control Hosp Epidemiol. 2010;31:99-101.

7. Sitzlar B, Deshpande A, Fertelli D, Kundrapu S, Sethi AK, Donskey CJ. An Environmental Disinfection Odyssey: Evaluation of Sequential Interventions to Improve Disinfection of Clostridium difficile Isolation Rooms. Infect Control Hosp Epidemiol. 2013;34:459-65.

8. Appelbaum E, Berg P, Frost A, Preuss G, Appelbaum E. The effects of work restructuring on low-wage, low-skilled workers in U.S. hospitals. In: Bernhadt A, Murnane R, editors. Low-wage America: How employers are reshaping opportunity in the workplace. New York: Russel Sage Foundation; 2003. p. 77-117.

9. Zuberi DM, Ptashnick MB. The deleterious consequences of privatization and outsourcing for hospital support work: the experiences of contracted-out hospital cleaners and dietary aids in Vancouver, Canada. Soc Sci Med. 2011;72:907-11.

10. Zoutman DE, Ford BD, Sopha K. Environmental cleaning resources and activities in Canadian acute care hospitals. Am J Infect Control. 2014:42:490-4.

11. Dumigan DG, Boyce JM, Havill NL, Golebiewski M, Balogun O, Rizvani R. Who is really caring for your environment of care? Developing standardized cleaning procedures and effective monitoring techniques. Am J Infect Control. 2010;38:387-92.

12. Anderson RE, Young V, Stewart M, Robertson C, Dancer SJ. Cleanliness audit of clinical surfaces and equipment: who cleans what? J Hosp Infect. 2011;78:178-81.

13. Ali S, Moore G, Wilson AP. Effect of surface coating and finish upon the cleanability of bed rails and the spread of Staphylococcus aureus. J Hosp Infect. 2012;80:192-8.

14. Cadnum JL, Hurless KN, Kundrapu S, Donskey CJ. Transfer of Clostridium difficile spores by nonsporicidal wipes and improperly used hypochlorite wipes: practice + product $=$ perfection. Infect Control Hosp Epidemiol. 2013;34:441-2.

15. Siani $\mathrm{H}$, Cooper C, Maillard JY. Efficacy of "sporicidal" wipes against Clostridium difficile. Am J Infect Control. 2011;39:212-8.

16. Engelbrecht K, Ambrose D, Sifuentes L, Gerba C, Weart I, Koenig D. Decreased activity of commercially available disinfectants containing quaternary ammonium compounds when exposed to cotton towels. Am J Infect Control. 2013:41:908-11.

17. Boyce JM, Sullivan L, Booker A, Baker J. Quaternary ammonium disinfectant issues encountered in an environmental services department. Infect Control Hosp Epidemiol. 2016;37:340-2.
18. Ramm L, Siani H, Wesgate R, Maillard JY. Pathogen transfer and high variability in pathogen removal by detergent wipes. Am J Infect Control. 2015;43:724-8

19. Weber DJ, Rutala WA, Sickbert-Bennett E. Outbreaks associated with contaminated antiseptics and disinfectants. Antimicrob Agents Chemother. 2007:51:4217-24.

20. Boyce JM, Havill NL, Tetro J, Sattar SA. Bacterial growth in an in-use hospital-grade quaternary ammonium-based disinfectant. Presented at the 21st Annual Scientific Meeting of the Society for Healthcare Epidemiology of America, April 2, 2011, Dallas, TX, abstr 113, 2011.

21. Kampf G, Degenhardt S, Lackner S, Jesse K, von Baum H, Ostermeyer C. Poorly processed reusable surface disinfection tissue dispensers may be a source of infection. BMC Infect Dis. 2014;14:37.

22. Eckstein BC, Adams DA, Eckstein EC, Rao A, Sethi AK, Yadavalli GK, et al. Reduction of Clostridium difficile and vancomycin-resistant Enterococcus contamination of environmental surfaces after an intervention to improve cleaning methods. BMC Infect Dis. 2007;7:61

23. French GL, Otter JA, Shannon KP, Adams NMT, Watling D, Parks MJ. Tackling contamination of the hospital environment by methicillin-resistant Staphylococcus aureus (MRSA): a comparison between conventional terminal cleaning and hydrogen peroxide vapour decontamination. J Hosp Infect. 2004;57:31-7.

24. Sigler V, Hensley S. Persistence of mixed staphylococci assemblages following disinfection of hospital room surfaces. J Hosp Infect. 2013;83:253-6.

25. Mitchell BG, Digney W, Locket P, Dancer SJ. Controlling methicillin-resistant Staphylococcus aureus (MRSA) in a hospital and the role of hydrogen peroxide decontamination: an interrupted time series analysis. BMJ Open. 2014:4:e004522.

26. Hayden MK, Bonten MJ, Blom DW, Lyle EA, van de Vijver DA, Weinstein RA. Reduction in acquisition of vancomycin-resistant Enterococcus after enforcement of routine environmental cleaning measures. Clin Infect Dis. 2006:42:1552-60.

27. Manian FA, Griesnauer S, Senkel D. Impact of terminal cleaning and disinfection on isolation of Acinetobacter baumannii complex from inanimate surfaces of hospital rooms by quantitative and qualitative methods. Am J Infect Control. 2013;41:384-5.

28. Strassle P, Thom KA, Johnson JK, Leekha S, Lissauer M, Zhu J, et al. The effect of terminal cleaning on environmental contamination rates of multidrug-resistant Acinetobacter baumannii. Am J Infect Control. 2012;40:1005-7.

29. Goodman ER, Platt R, Bass R, Onderdon AB, Yokoe DS, Huang SS. Impact of an environmental cleaning intervention on the presence of methicillinresistant Staphylococcus aureus and vancomycin-resistant enterococci on surfaces in intenstive care unit rooms. Infect Control Hosp Epidemiol. 2008:29:593-9.

30. Passaretti CL, Otter JA, Reich NG, Myers J, Shepard J, Ross T, et al. An evaluation of environmental decontamination with hydrogen peroxide vapor for reducing the risk of patient acquisition of multidrug-resistant organisms. Clin Infect Dis. 2013;56:27-35.

31. Mitchell BG, Dancer SJ, Anderson M, Dehn E. Risk of organism acquisition from prior room occupants: a systematic review and meta-analysis. J Hosp Infect. 2015;91:211-7.

32. Carling PC, Briggs JL, Perkins J, Highlander D. Improved cleaning of patient rooms using a new targeting method. Clin Infect Dis. 2006;42:385-8.

33. Boyce JM, Havill NL, Dumigan DG, Golebiewski M, Balogun O, Rizvani R. Monitoring the effectiveness of hospital cleaning practices using an ATP bioluminescence assay. Infect Control Hosp Epidemiol. 2009;30:678-84.

34. Rupp ME, Fitzgerald T, Sholtz L, Lyden E, Carling P. Maintain the gain: program to sustain performance improvement in environmental cleaning. Infect Control Hosp Epidemiol. 2014;35:866-8.

35. Alfa MJ, Lo E, Wald A, Dueck C, Degagne P, Harding GK. Improved eradication of Clostridium difficile spores from toilets of hospitalized patients using an accelerated hydrogen peroxide as the cleaning agent. BMC Infect Dis. 2010;10:268.

36. Rutala WA, Gergen MF, Weber DJ. Efficacy of improved hydrogen peroxide against important healthcare-associated pathogens. Infect Control Hosp Epidemiol. 2012;33:1159-61.

37. Boyce JM, Havill NL. Evaluation of a new hydrogen peroxide wipe disinfectant. Infect Control Hosp Epidemiol. 2013;34:521-3.

38. Alfa MJ, Lo E, Olson N, MacRae M, Buelow-Smith L. Use of a daily disinfectant cleaner instead of a daily cleaner reduced hospital-acquired infection rates. Am J Infect Control. 2015;43:141-6. 
39. Rutala WA, Gergen MF, Sickbert-Bennett EE, Williams DA, Weber DJ. Effectiveness of improved hydrogen peroxide in decontaminating privacy curtains contaminated with multidrug-resistant pathogens. Am J Infect Control. 2014:42:426-8.

40. Chiu S, Skura B, Petric M, McIntyre L, Gamage B, Isaac-Renton J. Efficacy of common disinfectant/cleaning agents in inactivating murine norovirus and feline calicivirus as surrogate viruses for human norovirus. Am J Infect Control. 2015:43:1208-12.

41. Carling PC, Perkins J, Ferguson J, Thomasser A. Evaluating a new paradigm for comparing surface disinfection in clinical practice. Infect Control Hosp Epidemiol. 2014;35:1349-55.

42. Deshpande A, Mana TS, Cadnum JL, Jencson AC, Sitzlar B, Fertelli D, et al. Evaluation of a sporicidal peracetic acid/hydrogen peroxide-based daily disinfectant cleaner. Infect Control Hosp Epidemiol. 2014;35:1414-6.

43. Meakin NS, Bowman C, Lewis MR, Dancer SJ. Comparison of cleaning efficacy between in-use disinfectant and electrolysed water in an English residential care home. J Hosp Infect. 2012;80:122-7.

44. Fertelli D, Cadnum JL, Nerandzic MM, Sitzlar B, Kundrapu S, Donskey CJ. Effectiveness of an electrochemically activated saline solution for disinfection of hospital equipment. Infect Control Hosp Epidemiol. 2013;34:543-4.

45. Stewart M, Bogusz A, Hunter J, Devanny I, Yip B, Reid D, et al. Evaluating use of neutral electrolyzed water for cleaning near-patient surfaces. Infect Control Hosp Epidemiol. 2014;35:1505-10.

46. Cahill OJ, Claro T, O'Connor N, Cafolla AA, Stevens NT, Daniels S, et al. Cold air plasma to decontaminate inanimate surfaces of the hospital environment. Appl Environ Microbiol. 2014;80:2004-10.

47. O'Connor N, Cahill O, Daniels S, Galvin S, Humphreys H. Cold atmospheric pressure plasma and decontamination. Can it contribute to preventing hospital-acquired infections? J Hosp Infect. 2014:88:59-65.

48. Claro T, Cahill OJ, O'Connor N, Daniels S, Humphreys H. Cold-air atmospheric pressure plasma against Clostridium difficile spores: a potential alternative for the decontamination of hospital inanimate surfaces. Infect Control Hosp Epidemiol. 2015:36:742-4.

49. Unal N, Yanik K, Karadag A, Odabasi H, Esen S, Gunaydin M. Evaluation of the efficacy of akacid plus(R) fogging in eradicating causative microorganism in nosocomial infections. Int J Clin Exp Med. 2014;7:5867-71.

50. Moore G, Griffith C. A laboratory evaluation of the decontamination properties of microfibre cloths. J Hosp Infect. 2006;64:379-85.

51. Rutala WA, Gergen MF, Weber DJ. Microbiologic evaluation of microfiber mops for surface disinfection. Am J Infect Control. 2007;35:569-73.

52. Moore G, Hall TJ, Wilson AP, Gant VA. The efficacy of the inorganic copperbased biocide CuWB50 is compromised by hard water. Lett Appl Microbiol. 2008;46:655-60.

53. Ali S, Moore G, Wilson AP. Spread and persistence of Clostridium difficile spores during and after cleaning with sporicidal disinfectants. J Hosp Infect. 2011;79:97-8.

54. Bergen LK, Meyer M, Hog M, Rubenhagen B, Andersen LP. Spread of bacteria on surfaces when cleaning with microfibre cloths. J Hosp Infect. 2009;71:132-7

55. Trajtman AN, Manickam K, Alfa MJ. Microfiber cloths reduce the transfer of Clostridium difficile spores to environmental surfaces compared with cotton cloths. Am J Infect Control. 2015:43:686-9.

56. Weber DJ, Rutala WA. Self-disinfecting surfaces: review of current methodologies and future prospects. Am J Infect Control. 2013:41:S31-5.

57. Humphreys $\mathrm{H}$. Self-disinfecting and microbiocide-impregnated surfaces and fabrics: what potential in interrupting the spread of healthcare-associated infection? Clin Infect Dis. 2014;58:848-53.

58. Schmidt MG, Attaway HH, Sharpe PA, John Jr J, Sepkowitz KA, Morgan A, et al. Sustained reduction of microbial burden on common hospital surfaces through introduction of copper. J Clin Microbiol. 2012;50:2217-23.

59. Schmidt MG, Attaway lii HH, Fairey SE, Steed LL, Michels HT, Salgado CD. Copper continuously limits the concentration of bacteria resident on bed rails within the intensive care unit. Infect Control Hosp Epidemiol. 2013;34:530-3

60. Salgado CD, Sepkowitz KA, John JF, Cantey JR, Attaway HH, Freeman KD, et al. Copper surfaces reduce the rate of healthcare-acquired infections in the intensive care unit. Infect Control Hosp Epidemiol. 2013:34:479-86.

61. Schweizer M, Graham M, Ohl M, Heilmann K, Boyken L, Diekema D. Novel hospital curtains with antimicrobial properties: a randomized, controlled trial. Infect Control Hosp Epidemiol. 2012;33:1081-5.
62. Kotsanas D, Wijesooriya WR, Sloane T, Stuart RL, Gillespie EE. The silver lining of disposable sporicidal privacy curtains in an intensive care unit. Am J Infect Control. 2014;42:366-70.

63. Baxa D, Shetron-Rama L, Golembieski M, Golembieski M, Jain S, Gordon M, et al. In vitro evaluation of a novel process for reducing bacterial contamination of environmental surfaces. Am J Infect Control. 2011;39:483-7.

64. Boyce JM, Havill NL, Guercia KA, Schweon SJ, Moore BA. Evaluation of two organosilane products for sustained antimicrobial activity on high-touch surfaces in patient rooms. Am J Infect Control. 2014;42:326-8.

65. Tamimi AH, Carlino S, Gerba CP. Long-term efficacy of a self-disinfecting coating in an intensive care unit. Am J Infect Control. 2014;42:1178-81.

66. Hedin G, Rynback J, Lore B. Reduction of bacterial surface contamination in the hospital environment by application of a new product with persistent effect. J Hosp Infect. 2010;75:112-5.

67. Page K, Wilson M, Parkin IP. Antimicrobial surfaces and their potential in reducing the role of the inanimate environment in the incidence of hospital-acquired infections. J Mater Chem. 2009;19:3819-31.

68. Park GW, Cho M, Cates EL, Lee D, Oh BT, Vinje J, et al. Fluorinated $\mathrm{TiO}(2)$ as an ambient light-activated virucidal surface coating material for the control of human norovirus. J Photochem Photobiol B. 2014;140:315-20.

69. Bogdan J, Zarzynska J, Plawinska-Czarnak J. Comparison of Infectious Agents Susceptibility to Photocatalytic Effects of Nanosized Titanium and Zinc Oxides: A Practical Approach. Nanoscale Res Lett. 2015;10:1023.

70. de Jong B, van Zanten ARH. Effect of MVX (titanium dioxide) on the microbial colonization of surfaces in an intensive care unit. Clinical Trials.gov identifier: NCT02348346, 2015.

71. Otter JA, Yezli S, Perl TM, Barbut F, French GL. The role of 'no-touch' automated room disinfection systems in infection prevention and control. J Hosp Infect. 2013:83:1-13.

72. Ottawa (ON): Canadian Agency for Drugs and Technologies in Health. Non-manual techniques for room disinfection in healthcare facilities: a review of clinical effectiveness and guidelines. 2014.

73. Andersen BM, Rasch M, Hochlin K, Jensen FH, Wismar P, Fredriksen JE. Decontamination of rooms, medical equipment and ambulances using an aerosol of hydrogen peroxide disinfectant. J Hosp Infect. 2006;62:149-55.

74. Shapey S, Machin K, Levi K, Boswell TC. Activity of a dry mist hydrogen peroxide system against environmental Clostridium difficile contamination in elderly care wards. J Hosp Infect. 2008;70:136-41.

75. Bartels MD, Kristoffersen K, Slotsbjerg T, Rohde SM, Lundgren B, Westh $H$. Environmental meticillin-resistant Staphylococcus aureus (MRSA) disinfection using dry-mist-generated hydrogen peroxide. J Hosp Infect. 2008;70:35-41.

76. Barbut F, Menuet D, Verachten M, Girou E. Comparison of the efficacy of a hydrogen peroxide dry-mist disinfection system and sodium hypochlorite solution for eradication of Clostridium difficile spores. Infect Control Hosp Epidemiol. 2009:30:507-14.

77. Piskin N, Celebi G, Kulah C, Mengeloglu Z, Yumusak M. Activity of a dry mist-generated hydrogen peroxide disinfection system against methicillinresistant Staphylococcus aureus and Acinetobacter baumannii. Am J Infect Control. 2011:39:757-62.

78. Landelle C, Legrand P, Lesprit P, Cizeau F, Ducellier D, Gouot C, et al. Protracted outbreak of multidrug-resistant Acinetobacter baumannii after intercontinental transfer of colonized patients. Infect Control Hosp Epidemiol. 2013:34:119-24

79. Best EL, Parnell P, Thirkell G, Verity P, Copland M, Else P, et al. Effectiveness of deep cleaning followed by hydrogen peroxide decontamination during high Clostridium difficile infection incidence. J Hosp Infect. 2014;87:25-33.

80. Fichet G, Antioga K, Comoy E, Deslys JP, McDonnell G. Prion inactivation using a new gaseous hydrogen peroxide sterilisation process. J Hosp Infect. 2007:67:278-86

81. Heckert RA, Best M, Jordan LT, Dulac GC, Eddington DL, Sterritt WG. Efficacy of vaporized hydrogen peroxide against exotic animal viruses. Appl Environ Microbiol. 1997:63:3916-8.

82. Rogers JV, Sabourin CL, Choi YW, Richter WR, Rudnicki DC, Riggs KB, et al. Decontamination assessment of Bacillus anthracis, Bacillus subtilis, and Geobacillus stearothermophilus spores on indoor surfaces using a hydrogen peroxide gas generator. J Appl Microbiol. 2005:99:739-48.

83. Pottage T, Richardson C, Parks S, Walker JT, Bennett AM. Evaluation of hydrogen peroxide gaseous disinfection systems to decontaminate viruses. J Hosp Infect. 2010;74:55-61.

84. Ray A, Perez F, Beltramini AM, Jakubowycz M, Dimick P, Jacobs MR, et al. Use of vaporized hydrogen peroxide decontamination during an outbreak 
of multidrug-resistant Acinetobacter baumannii infection at a long-term acute care hospital. Infect Control Hosp Epidemiol. 2010;31:1236-41.

85. Galvin S, Boyle M, Russell RJ, Coleman DC, Creamer E, O'Gara JP, et al. Evaluation of vaporized hydrogen peroxide, Citrox and $\mathrm{pH}$ neutral Ecasol for decontamination of an enclosed area: a pilot study. J Hosp Infect. 2012:80:67-70

86. Chmielarczyk A, Higgins PG, Wojkowska-Mach J, Synowiec E, Zander E, Romaniszyn D, et al. Control of an outbreak of Acinetobacter baumannii infections using vaporized hydrogen peroxide. J Hosp Infect. 2012;81:239-45.

87. Bates CJ, Pearse R. Use of hydrogen peroxide vapour for environmental control during a Serratia outbreak in a neonatal intensive care unit. J Hosp Infect. 2005;61:364-6.

88. Hall L, Otter JA, Chewins J, Wengenack NL. Use of hydrogen peroxide vapor for deactivation of Mycobacterium tuberculosis in a biological safety cabinet and a room. J Clin Microbiol. 2007;45:810-5.

89. Hall L, Otter JA, Chewins J, Wengenack NL. Deactivation of the dimorphic fungi Histoplasma capsulatum, Blastomyces dermatitidis and Coccidioides immitis using hydrogen peroxide vapor. Med Mycol. 2008;46:189-91.

90. Boyce JM, Havill NL, Otter JA, McDonald LC, Adams NMT, Cooper T, et al. Impact of hydrogen peroxide vapor room decontamination on Clostridium difficile environmental contamination and transmission in a healthcare setting. Infect Control Hosp Epidemiol. 2008;29:723-9.

91. Otter JA, French GL. Survival of nosocomial bacteria and spores on surfaces and inactivation by hydrogen peroxide vapor. J Clin Microbiol. 2009;47:205-7.

92. Manian FA, Griesenauer S, Senkel D, Setzer JM, Doll SA, Perry AM, et al. Isolation of Acinetobacter baumannii complex and methicillin-resistant Staphylococcus aureus from hospital rooms following terminal cleaning and disinfection: can we do better? Infect Control Hosp Epidemiol. 2011;32:667-72.

93. Barbut F, Yezli S, Mimoun M, Pham J, Chaouat M, Otter JA. Reducing the spread of Acinetobacter baumannii and methicillin-resistant Staphylococcus aureus on a burns unit through the intervention of an infection control bundle. Burns. 2013;39:395-403.

94. Jeanes A, Rao G, Osman M, Merrick P. Eradication of persistent environmental MRSA. J Hosp Infect. 2005;61:85-6.

95. Dryden M, Parnaby R, Dailly S, Lewis T, Davis-Blues K, Otter JA, et al. Hydrogen peroxide vapour decontamination in the control of a polyclonal meticillin-resistant Staphylococcus aureus outbreak on a surgical ward. J Hosp Infect. 2008;68:190-2.

96. Otter JA, Yezli S, Schouten MA, van Zanten AR, Houmes-Zielman G, Nohlmans-Paulssen MK. Hydrogen peroxide vapor decontamination of an intensive care unit to remove environmental reservoirs of multidrugresistant gram-negative rods during an outbreak. Am J Infect Control. 2010;38:754-6

97. Cooper T, O'Leary M, Yezli S, Otter JA. Impact of environmental decontamination using hydrogen peroxide vapour on the incidence of Clostridium difficile infection in one hospital Trust. J Hosp Infect. 2011;78:238-40.

98. Snitkin ES, Zelazny AM, Thomas PJ, Stock F, Henderson DK, Palmore TN, et al. Tracking a hospital outbreak of carbapenem-resistant Klebsiella pneumoniae with whole-genome sequencing. Sci Transl Med. 2012;4:148ra116.

99. Gopinath R, Savard P, Carroll KC, Wilson LE, Landrum BM, Perl TM. Infection prevention considerations related to New Delhi metallo-beta-lactamase Enterobacteriaceae: a case report. Infect Control Hosp Epidemiol. 2013;34:99-100

100. Otter JA, Nowakowski E, Salkeld JA, Duclos M, Passaretti CL, Yezli S, et al. Saving Costs through the Decontamination of the Packaging of Unused Medical Supplies Using Hydrogen Peroxide Vapor. Infect Control Hosp Epidemiol. 2013;34:472-8.

101. Otter JA, Barnicoat M, Down J, Smyth D, Yezli S, Jeanes A. Hydrogen peroxide vapour decontamination of a critical care unit room used to treat a patient with Lassa fever. J Hosp Infect. 2010;75:335-7.

102. Otter JA, Mepham S, Athan B, Mack D, Smith R, Jacobs M, et al. Terminal decontamination of the Royal Free London's high-level isolation unit after a case of Ebola virus disease using hydrogen peroxide vapor. Am J Infect Control. 2016;44:233-5.

103. Otter JA, Puchowicz M, Ryan D, Salkeld JAG, Cooper TA, Havill NL, et al. Assessing the feasibility of routine use of hydrogen peroxide vapor (HPV) to decontaminate rooms in a busy US hospital. Infect Control Hosp Epidemiol. 2009;30:574-7.
104. Berrington AW, Pedler SJ. Investigation of gaseous ozone for MRSA decontamination of hospital side-rooms. J Hosp Infect. 1998;40:61-5.

105. de Boer HEL, van Elzelingen-Dekker CM, van Rheenen-Verberg CMF, Spanjaard L. Use of gaseous ozone for eradication of methicillin-resistant Staphylococcus aureus from the home environment of a colonized hospital employee. Infect Control Hosp Epidemiol. 2006;27:1120-2.

106. Sharma M, Hudson JB. Ozone gas is an effective and practical antibacterial agent. Am J Infect Control. 2008;36:559-63.

107. Davies A, Pottage T, Bennett A, Walker J. Gaseous and air decontamination technologies for Clostridium difficile in the healthcare environment. J Hosp Infect. 2011;77:199-203.

108. Gibbs SG, Lowe JJ, Smith PW, Hewlett AL. Gaseous chlorine dioxide as an alternative for bedbug control. Infect Control Hosp Epidemiol. 2012;33:495-9.

109. Sexton JD, Tanner BD, Maxwell SL, Gerba CP. Reduction in the microbial load on high-touch surfaces in hospital rooms by treatment with a portable saturated steam vapor disinfection system. Am J Infect Control. 2011;39:655-62.

110. Nernandzic MM, Cadnum JL, Pultz MJ, Donskey CJ. Evaluation of an automated ultraviolet radiation device for decontamination of Clostridium difficile and other healthcare-associated pathogens in hospital rooms. BMC Infect Dis. 2010;10:197.

111. Rutala WA, Gergen MF, Weber DJ. Room decontamination with UV radiation. Infect Control Hosp Epidemiol. 2010;31:1025-9.

112. Boyce JM, Havill NL, Moore BA. Terminal decontamination of patient rooms using an automated mobile UV light unit. Infect Control Hosp Epidemiol. 2011;32:737-42

113. Rutala WA, Gergen MF, Tande BM, Weber DJ. Rapid hospital room decontamination using ultraviolet (UV) light with a nanostructured UV-reflective wall coating. Infect Control Hosp Epidemiol. 2013;34:527-9.

114. Anderson DJ, Gergen MF, Smathers E, Sexton DJ, Chen LF, Weber DJ, et al. Decontamination of targeted pathogens from patient rooms using an automated ultraviolet-C-emitting device. Infect Control Hosp Epidemiol. 2013;34:466-71.

115. Mahida N, Vaughan N, Boswell T. First UK evaluation of an automated ultraviolet-C room decontamination device (Tru-D). J Hosp Infect. 2013;84:332-5.

116. Nerandzic MM, Fisher CW, Donskey CJ. Sorting through the wealth of options: comparative evaluation of two ultraviolet disinfection systems. PLoS One. 2014;9:e107444

117. Rutala WA, Gergen MF, Tande BM, Weber DJ. Room decontamination using an ultraviolet- $C$ device with short ultraviolet exposure time. Infect Control Hosp Epidemiol. 2014;35:1070-2.

118. Rutala WA, Weber DJ, Gergen MF, Tande BM, Sickbert-Bennett EE. Does coating all room surfaces with an ultraviolet $C$ light-nanoreflective coating improve decontamination compared with coating only the walls? Infect Control Hosp Epidemiol. 2014;35:323-5

119. Havill NL, Moore BA, Boyce JM. Comparison of the microbiological efficacy of hydrogen peroxide vapor and ultraviolet light processes for room decontamination. Infect Control Hosp Epidemiol. 2012;33:507-12.

120. Anderson DJ, Sexton DJ. Effectiveness of enhanced terminal room disinfection to prevent healthcare-associated infections (HAls). Clinical Trials. gov identifier: NCT01579370, 2015.

121. Stibich M, Stachowiak J, Tanner B, Berkheiser M, Moore L, Raad I, et al. Evaluation of a pulsed-xenon ultraviolet room disinfection device for impact on hospital operations and microbial reduction. Infect Control Hosp Epidemiol. 2011;32:286-8.

122. Levin J, Riley LS, Parrish C, English D, Ahn S. The effect of portable pulsed xenon ultraviolet light after terminal cleaning on hospital-associated Clostridium difficile infection in a community hospital. Am J Infect Control. 2013:41:746-8

123. Jinadatha C, Quezada R, Huber TW, Williams JB, Zeber JE, Copeland LA. Evaluation of a pulsed-xenon ultraviolet room disinfection device for impact on contamination levels of methicillin-resistant Staphylococcus aureus.

BMC Infect Dis. 2014:14:187.

124. Ghantoji SS, Stibich M, Stachowiak J, Cantu S, Adachi JA, Raad II, et al. Non-inferiority of pulsed xenon UV light versus bleach for reducing environmental Clostridium difficile contamination on high-touch surfaces in Clostridium difficile infection isolation rooms. J Med Microbiol. 2015;64:191-4.

125. Sander J, Ladenstein M. Reliability of disinfectant dispensers in hospitals (author's transl). Dtsch Med Wochenschr. 1974;99:1560-4. 
126. Nagaraja A, Visintainer P, Haas JP, Menz J, Wormser GP, Montecalvo MA. Clostridium difficile infections before and during use of ultraviolet disinfection. Am J Infect Control. 2015;43:940-5.

127. Miller R, Simmons S, Dale C, Stibich M, Stachowiak J. Utilization and impact of a pulsed-xenon ultraviolet room disinfection system and multidisciplinary care team on Clostridium difficile in a long-term acute care facility. Am J Infect Control. 2015;43:1350-3.

128. McMullen K, Wood H, Buol W, Johnson D, Bradley A, Woeltje K, et al. Impact of a pulsed xenon ultraviolet light (PX-UV) light room disinfection system on Clostridium difficile rates. Presented at IDWeek 2015, abstract 1714, October 10, 2015, San Diego, CA. 2015.

129. Nerandzic MM, Thota P, Sankar CT, Jencson A, Cadnum JL, Ray AJ, et al. Evaluation of a pulsed xenon ultraviolet disinfection system for reduction of healthcare-associated pathogens in hospital rooms. Infect Control Hosp Epidemiol. 2015:36:192-7.

130. Maclean M, MacGregor SJ, Anderson JG, Woolsey GA, Coia JE, Hamilton K, et al. Environmental decontamination of a hospital isolation room using high-intensity narrow-spectrum light. J Hosp Infect. 2010;76:247-51.

131. Bache SE, Maclean M, MacGregor SJ, Anderson JG, Gettinby G, Coia JE, et al. Clinical studies of the High-Intensity Narrow-Spectrum light Environmental Decontamination System (HINS-light EDS), for continuous disinfection in the burn unit inpatient and outpatient settings. Burns. 2012;38:69-76.

132. Maclean M, McKenzie K, Anderson JG, Gettinby G, MacGregor SJ. 405 nm light technology for the inactivation of pathogens and its potential role for environmental disinfection and infection control. J Hosp Infect. 2014:88:1-11.

133. Cram N, Shipman N, Quarles JM. Reducing airborne microbes in the surgical operating theater \& other clinical settings: A study utilizing the AiroCide System. J Clin Engineering. 2004;79-88.

\section{Submit your next manuscript to BioMed Central and we will help you at every step:}

- We accept pre-submission inquiries

- Our selector tool helps you to find the most relevant journal

- We provide round the clock customer support

- Convenient online submission

- Thorough peer review

- Inclusion in PubMed and all major indexing services

- Maximum visibility for your research

Submit your manuscript at www.biomedcentral.com/submit

C Biomed Central 